\title{
Geometric morphometric differentiation and allometric growth in the populations of Littorina saxatilis from the White and the Barents Sea
}

\author{
Z.I. Starunova1, ${ }^{1,}$, N.A. Mikhailova2 ${ }^{2}$, A.I. Granovitch ${ }^{3}$ \\ ${ }^{1}$ Zoological Institute of Russian Academy of Science, Universitetskaya nab. 1, St. Petersburg, \\ 199034, Russia. \\ ${ }^{2}$ Institute of Cytology of Russian Academy of Science, Tikhoretsky ave., 4, St. Petersburg, 194064, \\ Russia. \\ ${ }^{3}$ St. Petersburg State University, Universitetskaya nab. 7-9, St. Petersburg, 199034, Russia. \\ * Corresponding author: zinaida.starunova@zin.ru
}

ABSTRACT: Populations of intertidal molluscs Littorina saxatilis from the White and the Barents Sea living under conditions of varying degrees of wave exposure were morphometrically investigated by populational samples and individual growth analyses. The molluscs from all the studied populations were characterized by an allometric shell growth, but the characteristics of the allometry were different in populations from places with a different degree of wave impact. The shell shape of L. saxatilis embryos (a starting point for allometric growth) differed neither between regions nor between populations with different wave action. However, an analysis of successive age cohorts demonstrated that a rapid growth in the first 2-3 years of life was accompanied by considerable allometric changes specific for strongly and moderately exposed shores. Consequently, the molluscs older than three years acquired a typical "exposed" or "moderate" shell morphotypes. Comparison of populational and individual growth data from the same populations revealed a similarity of the coefficients of variation. These observations support the hypothesis that the shell form differences in the populations under conditions of different wave action are established not by the ongoing selection of the specific "exposed" or "moderate" shell form but by the implementation of different specific allometric growth programs depending on the environment. Therefore, we propose that the wave action is not a "proximate" but the "ultimate" cause of the shell differences. The features of the allometric growth are already formed in different populations and apparently become a population-specific inherited allometric growth program.

How to site this article: Starunova Z.I., Mikhailova N.A., Granovitch A.I. 2021. Geometric morphometric differentiation and allometric growth in the populations of Littorina saxatilis from the White and the Barents Sea // Invert. Zool. Vol.18. No.4. P.502-522. doi: 10.15298/ invertzool.18.4.06

KEY WORDS: Littorina saxatilis, geometric morphometrics, shell shape. 


\title{
Морфометрические различия и аллометрический рост в популяциях Littorina saxatilis Белого и Баренцева морей
}

\author{
3.И. Старунова ${ }^{1, *}$, Н.А. Михайлова², А.И. Гранович \\ I Зоологический институт РАН, Университетская наб. 1, Санкт-Петербург, 199034, Рос- \\ сия. \\ ${ }^{2}$ Институт ицитологии РАН, Тихореикий пр., 4, Санкт-Петербург, 194064, Россия. \\ ${ }^{3}$ Санкт-Петербургский государственный университет, Университетская наб. 7-9, Санкт- \\ Петербург, 199034, Россия. \\ * Corresponding author: zinaida.starunova@zin.ru
}

РЕЗЮМЕ: Популяции литоральных моллюсков Littorina saxatilis из Баренцева и Белого морей, обитающих в условиях разной степени волнового воздействия, исследованы с помощью методов геометрической морфометрии. Применялись два подхода: анализ популяционных выборок и исследование индивидуальных особенностей роста. Данные обоих анализов свидетельствуют о наличии алометрических особенностей роста во всех исследованных популяциях. Однако характер аллометрии различен в популяциях из мест, различающихся по степени волнового воздействия. Форма раковины эмбрионов L. saxatilis (начальная точка для аллометрического роста) не различается ни между географическими регионами, ни между популяциями с различным волновым воздействием. Однако анализ раковин моллюсков последовательных возрастных когорт показал, что быстрый рост в первые 2-3 года жизни сопровождался значительными аллометрическими изменениями, специфическими для мест с различной степенью воздействия волнового прибоя. Как следствие, моллюски старше 3 лет приобретают типичный «прибойный» и «умеренный» морфотипы раковины. Сравнение популяционных данных и результатов анализа индивидуального роста в одних и тех же популяциях выявило сходство коэффициентов вариации. Это свидетельствует в пользу гипотезы о том, что связанные с прибойностью местообитаний особенности формы раковины взрослых моллюсков формируются не за счет действующей дифференциальной смертности моллюсков с отклоняющимися морфометрическими характеристиками, а за счет реализации разных программ аллометрического роста соответственно в «прибойных» и более закрытых от действия волн местообитаниях. Таким образом, мы можем предположить, что волновое воздействие можно рассматривать не в качестве непосредственной (proximate), но в качестве конечной (ultimate) причины различий аллометрического роста раковины. В популяциях реализуются сформированные ранее ростовые аллометрические программы, специфика которых определяется сочетанием факторов в данном местообитании.

Как цитировать эту статью: Starunova Z.I., Mikhailova N.A., Granovitch A.I. 2021. Geometric morphometric differentiation and allometric growth in the populations of Littorina saxatilis from the White and the Barents Sea // Invert. Zool. Vol.18. No.4. P.502522. doi: 10.15298/invertzool.18.4.06

КЛЮЧЕВЫЕ СЛОВА: Littorina saxatilis, геометрическая морфометрия, форма раковины. 


\section{Introduction}

Intraspecific morphometric differences between individuals are important features characterizing the structure of species from various taxonomic groups. They represent both the genetic heterogeneity between the populations and the plasticity of the characters due to the impact of ecological factors. Morphometric differences between individuals of different populations may reflect the stages of the speciation process. Morphometric differentiation of populations under conditions of a contrasting impact of a certain ecological factor may shed light on the mechanisms of microevolutionary divergence of the species.

The idea that shape variation is controlled by different allometric ontogenetic programs was proposed by Gould (1966). The term allometric (versus isometric) growth denotes relative changes in the relationship of the size of a body part and the size of the body as a whole during ontogenesis. The sequence of the allometric changes throughout a specific ontogeny is an allometric program (Gould, 1966), whereas intraspecific variability of allometric programs consists of several successive levels of variability: individual (ontogenetic) variation, variation within the population (static allometry), and evolutionary changes (Gould, 1966; Klingenberg, 1996). Ontogenetic variation in populations can be assessed both by direct longitudinal data, that is, data from a single individual taken at different growth stages (Gould, 1966; Cock, 1966) or by mass sample data (Gould, 1966, = cross sectional data, Cock, 1966), that is, an indirect assessment of allometry by the comparison of "static" parameters of different individuals at different growth stages. In studies of ontogenetic allometry by mass sample data, each individual is measured once at a single size/age, and the set of measurements from different individuals of the population gives average allometric trajectory. Mass sample data, obtained in such way may underestimate strong selection in action. Oppositely, the longitudinal data approach, which supposes "reconstruction" of the growth of the same individual by successive measurements, was applied only in a few studies on molluscs and insects (Kemp, Bertness, 1984; Iglesias et al., 2008) because of methodological difficulties. This approach can bring very important additional information because permits to assess allometric trajectories considering individual variability. The "longitudinal" and "mass sample (cross sectional)" data from the same population may yield the same result or differ significantly if strong natural selection on morphometric characters is at work in a specific place or there are environmentally dependent strong growth changes in a specific lifetime period of studied individuals (Urdy et al., 2010).

Gastropods are useful objects for obtaining reliable morphometric data characterizing the population structure by the shell shape. Shell growth trajectories can be recovered both from fossil material and adult mollusk shell with longitudinal approach. Longitudinal data represent shell shape of a mollusc as a result of growth steps along a coiling axis through life. This approach get advantage in paleontological studies and computer modeling (Urdy et al., 2010).

The rough periwinkles Littorina saxatilis (Olivi, 1792) is a particularly convenient natural model, as it is characterized by a diverse morphometric differentiation(Rolán-Alvarezet al. 2015). Populations of this intertidal snail are widespread along the shores of the North Atlantic and are a popular model for ecological and evolution studies. L. saxatilis has a low dispersal ability. Being ovoviviparous, these molluscs lack the dispersal larva stage, and the range of individual mobility of adult rough periwinkles is limited to several meters. As a consequence they can form local populations composed of local forms or ecotypes (Reid, 1996; Janson, 1982 a,b; Johannesson et al., 1993; RolánAlvarez et al., 1997; Galindo, Grahame, 2014), geographical morphs and cryptic species (Reid, 1996). These intraspecific forms exhibit a significant morphological and genetic differentiation, accompanied by a partial reproductive isolation(Johannesson et al., 1993; 1995; RolánAlvarez et al., 1999; Grahame et al., 2006; 
Panova et al., 2006; Hollander, Butlin, 2010; Butlin et al., 2014; Chrismas et al., 2014; Galindo, Grahame, 2014), along with the formation of micro-scale hybrid zones between subpopulations of ecotypes (Johannesson et al., 1993; 1995; Rolán-Alvarez et al., 1999; Grahame et al., 2006; Panova et al., 2006).

Wave action is a significant factor affecting morphological differences between the populations of L. saxatilis in Europe (Janson, 1982b; 1983; Johannesson, Johannesson, 1996, Carvajal-Rodríguez et al., 2005). Individuals from populations exposed to stronger wave action generally have a flattened shell with a respectively larger aperture. Differences in shell shape appear be adaptive as they increase the probability of survival under specific conditions, as confirmed by transplantation recapture experiments (Janson, 1983; Rolán-Alvarez et al., 1997). Despite the instances of phenotypic plasticity, the divergent forms of shells in "wave exposed" and "sheltered" populations are largely inherited (Hollander, Butlin, 2010), as confirmed in common garden and transplantation experiments (Janson, 1982b; Johannesson, Johannesson, 1990; Boulding, Hay, 1993 [for Littorina sp.]; Johannesson, Johannesson, 1996; Hollander et al., 2006).

Though a large amount of research has been done on European populations of L. saxatilis, we are the first to focus on the morphological differences of Littorina species at the northeast Arctic edge of their distribution (the White and the Barents Sea). There are no ecotypes with significant morphological distinctions in the populations of L. saxatilis from these seas (Starunova et al., 2010). Habitat conditions in these regions differ considerably from those at the European coasts of the North Atlantic. Severe winters at both seas affect the intertidal community and prevent year-round shell growth of L. saxatilis, leading to the formation of the winter growth stop rings on the shell. This periodicity may be the reason why $L$. saxatilis individuals in these regions have a comparatively long lifespan, 8-10 and even 12 years (Matveeva, 1974). Besides, winter growth stop rings make it possible to define the age of every individual, which is especially important for allometric growth investigation.

Geometric morphometry is a powerful tool for shape variation studies (Rohlf, 1990) as it allows one to combine direct quantification and morphological description. The analysis also eliminates isometric size variation (Adams, Rohlf, Slice, 2004), but the "size" still can be a factor. Thus, geometric morphometric methods can be performed for allometric studies, especially when the shape changes during the growth of the organism. Geometric morphometry was successfully used to separate ecotypes and to reveal convincing morphological differences between L. saxatilis in E and S Swedish ecotypes occurring in contrasting habitats (Hollander et al., 2006), SU and RB morphs at the Atlantic coast of Spain (Carvajal-Rodríguezet al., 2005), and $\mathrm{H}$ and $\mathrm{M}$ morphs at the shore of Northeast England (Conde-Padín et al., 2007). Despite the fact that mass sample approach has been used widely for both interspecific and intraspecific analysis of Littorina populations (see reviews Rolán-Alvarez et al. 2015; Johannesson, Johannesson, 1990; Carvajal-Rodríguez et al., 2005), the only example of longitudinal approach in relation to Littorina species is mother-offspring analysis based on common garden experiments (Newkirk, Doyle, 1975).

In this study, (1) we analyzed the morphometric differentiation of $L$. saxatilis populations in the northeastern part of its distribution; (2) we present the data on the features of long-term allometric growth of L. saxatilis snails, using a natural possibility of assessing their age; and, finally, (3) we analyzed the data obtained by longitudinal and by mass sample approach to verify the idea of "allometric growth programs" from populations under different wave action. To obtain longitudinal data, we analyzed the shell sections of adult snails. Morphometric reconstructions of the growth stages of an individual were performed from each slice, using successive "snapshots" corresponding to the morphometric parameters of a given individual in successive age groups. For the analysis of "allometric growth programs" we used all age cohorts starting with shelled embryos. Finally, 


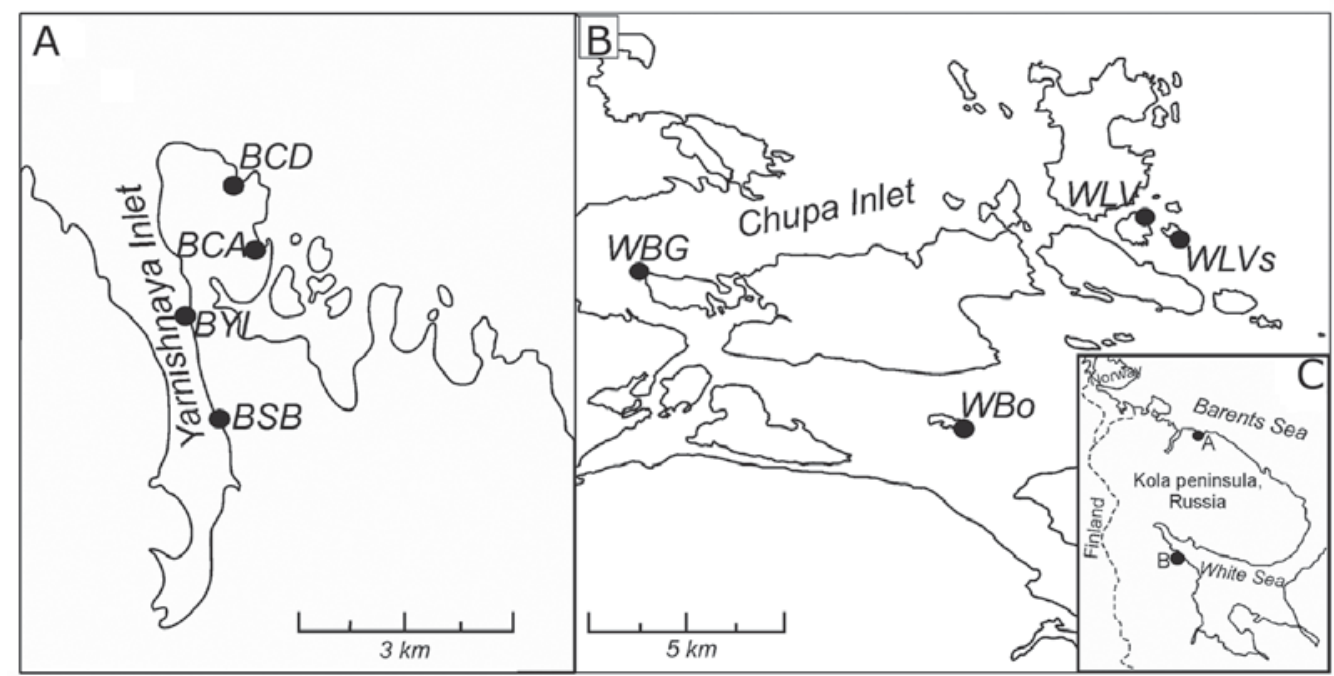

Fig. 1. Map of sampling locations. A - Yarnishnaya Inlet of the Barents Sea; B - Chupa Inlet of the Kandalaksha Bay of the White Sea; C - large-scale map showing the sites on (A) and (B).

Abbreviations: BSB - Spring Bobrovy; BYI - Yarnishnaya Inlet; BCA - Cape Avariyniy; BCD — Cape Dernisty; WBG - Bolshoi Gorely island; WBo - Bortshovets island; WLV — Luda Vitchennaya island; WLVs - Luda Visokaya island

Рис. 1. Карта сборов. А — губа Ярнышная Баренцева моря; В — губа Чупа, Кандалакшский залив Белого моря; C - общая карта с местами сборов (А) и (B).

Обозначения: BSB - Бобровый ручей; BYI - губа Ярнышная; BCA — мыс Аварийный; BCD — мыс Дернистый; WBG - остров Большой горелый; WBo - остров Борщовец; WLV — остров луда Виченная; WLVs - остров луда Высокая.

we compared the ontogenetic trajectories based on both the "mass sample" approach and the "longitudinal data" within the same population. Our null hypothesis concerns that ontogenetic change in size and shape in populations can be reflected both by "longitudinal data" and "mass sample" data, but less variable in ontogenetic trajectories. Our results might provide a model of growth in populations of $L$. saxatilis and draw some conclusions regarding the ongoing selection based on morphometric characteristics.

\section{Materials and methods}

\section{Populations and samples}

L. saxatilis was collected in two geographical regions (Fig. 1): the Chupa Inlet of the Kandalaksha Bay of the White Sea and the Eastern Murman in the Barents Sea. We examined four distinct populations living on the shore under strong wave action (hereafter referred to as "exposed" populations) or under moderately strong wave action ("moderate" populations) in each region. Abbreviated population codes and sample characteristics are given in Table 1. At all the sites, the snails were collected during low tide from the stones, boulders or gravel of the upper shore, between the levels of mean high water spring (MHWS) and mean low water neap (MHWN).

The shells were measured (precision 0.1 $\mathrm{mm}$ ) and photographed; the age of individual molluscs was determined from annual growth checks, as described earlier (Granovitch et al., 2000). Then every snail was anaesthetized and dissected under a binocular microscope (MBI10; and Leica M205C) for reliable species identification. This was particularly important for the samples from the Barents Sea, where cryptic L. arcana and L. compressa co-occur with L. saxatilis in sympatric populations (Granovitch et al., 2004). All individuals infected with 


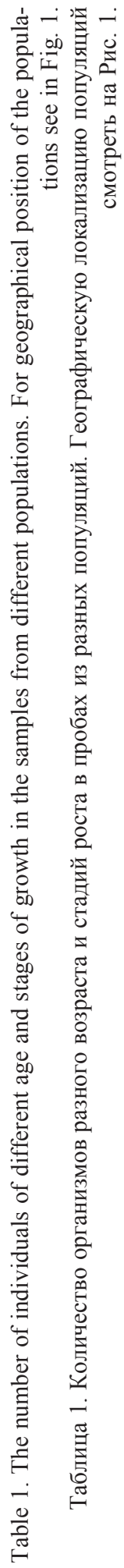

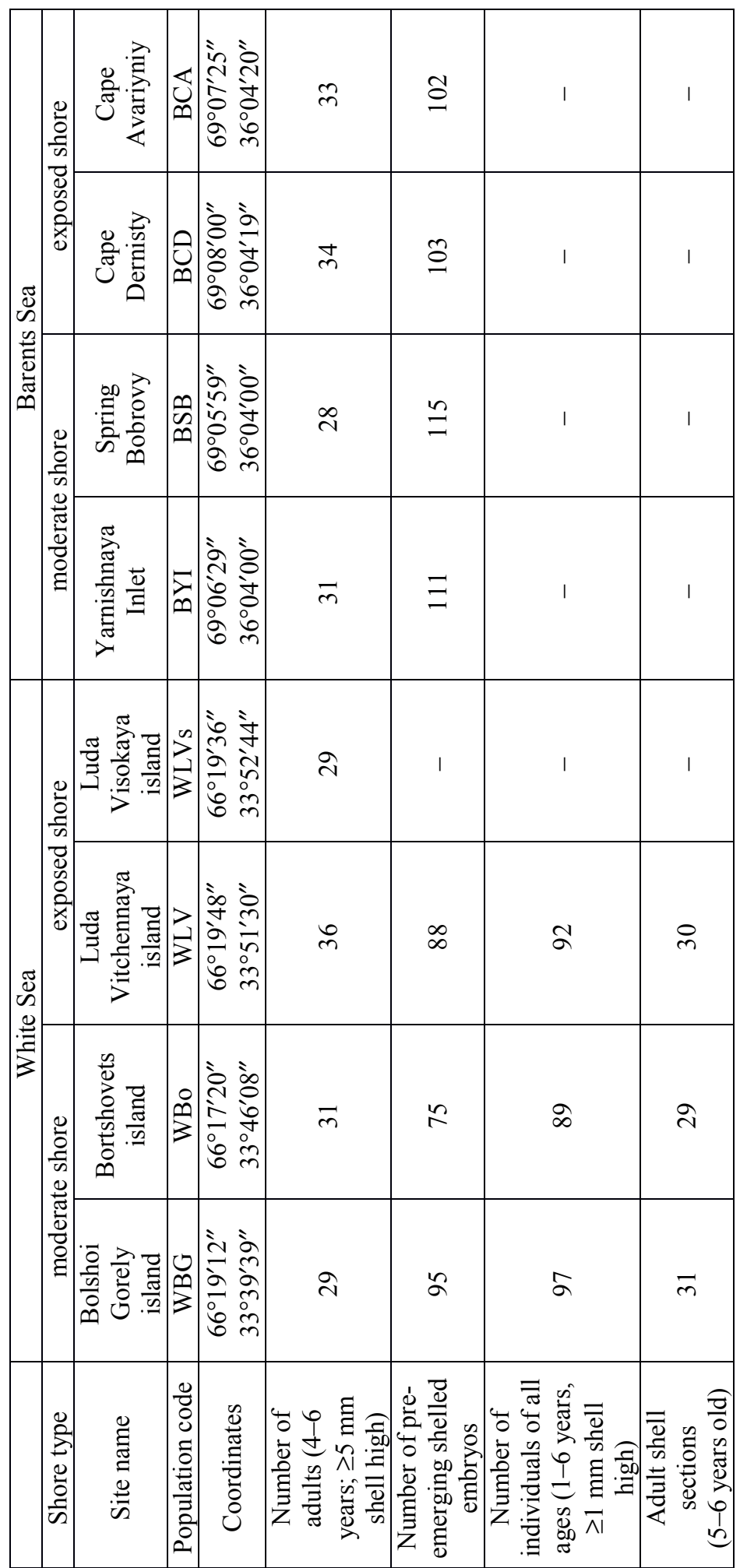


trematodes were excluded from the further study. Males and females were equally represented in the samples.

Ten uninfected females aged 4-5 years with mature brood pouches were chosen from each of 7 populations except (WLVs, see Table 1) to obtain embryos. Approximately 8-12 shelled embryos were taken directly from each brood pouch. For our study, we chose pre-emerging snails with 1.5-2 shell whorls without any abnormalities.

The sample sizes from different populations are presented in Table 1. We analyzed different types of samples in our study:

1. mature molluscs aged 4-6 years $(\geq 5 \mathrm{~mm}$ shell height) from all the eight populations (Fig. 2A-D) for analysis of adult shape;

2. from eight to twelve pre-emerging shelled embryos with 1.5-2 shell whorls from the brood pouch of each of the 10 females from seven populations (except WLVs) (Fig. 2E, F) for the analysis of embryonic shape;

3. molluses of all age groups from 1 to 6 years old ( $\geq 1 \mathrm{~mm}$ shell high) from the three model populations (WLV, WBG and WBo) (Fig. 3C) for estimation of mass sample data (cross section sensu Gould, 1966). The youngest individuals in this study were recently hatched molluscs, most of which had hatched in August the year before the collection and had one growth check after the winter;

4. the shell sections of adult snails of three model populations (WLV, WBG and WBo) for understanding the individual growth trajectories (series through ontogeny: sequential measurement of the same individual during its growth) to estimate longitudinal data. Before sectioning, the shells were boiled to remove the tissues. We made thin sections of the shells using a grinding wheel and fine sandpaper of different grits and held the coiling axis and aperture plane of the shells oriented parallel to the polishing plane. The thin sections represented all the whorls of the shell, sectioned at the level of columella (Fig. 3A, B). Therefore, the series of thin sections of the same shell depicted the ontogenetic changes of the individual.
We characterized the successive growth stages of the same individual using a full set of landmarks and analyzing every shell section several times (Fig. 3A, B). Every slide was conditionally divided into the regions corresponding to the size of molluscs $1,2,3$, etc. years old, based on a size-age approximation of the mean linear shell parameters (shell height and width) (Kozminsky, 2006).

\section{Geometric morphometric and statis-} tical methods

Landmark-based geometric morphometric techniques were used to analyze the shell shape of $L$. saxatilis from ecologically different habitats and geographical locations. For two-dimensional morphogeometric analysis, each shell was oriented to a standard position and photographed with a digital camera. The shells were oriented on a stable stand or a microscope base with the coiling axis parallel to the plane of the lens (with a mm scale in the plane of focus). Images of embryos and shell sections were made using a binocular microscope Leica M205C with a DFC 495 camera and LAS ver. 4.0.0 software.

Shell shape variables were estimated by placing two different sets of landmarks (LMs) on each image using the TPS Dig program ver. 2.16 developed by Rohlf (2005a): a set of 18 LM for adults (Fig. 2A-D) and juveniles; and 11 LM for embryos and shell sections (Fig. 2E, F). The placement of $18 \mathrm{LMs}$ represented the main shell measurements: LM 1, LM 11 and LM 13 referred to the columella axis; LM 7 and LM 15 resided on the axis perpendicular to the columella; LM 9, LM 13 and LM 14, LM 2, LM 4, LM 6, LM 16 and LM 18 were located in the seam of the coils. LM 3, LM 5, LM 15 and LM 17 were positioned on the center of the coils. LMs 7 to 13 described the shape of the aperture. The set with the $11 \mathrm{LMs}$ was placed on the same positions as the set of the $18 \mathrm{LMs}$, except the LMs that referred to spires. For further statistical analysis, the shell shape variables centroid size (CS), uniform components (the first uniform component U1 and the second uniform component U2) and non-uniform components 
A

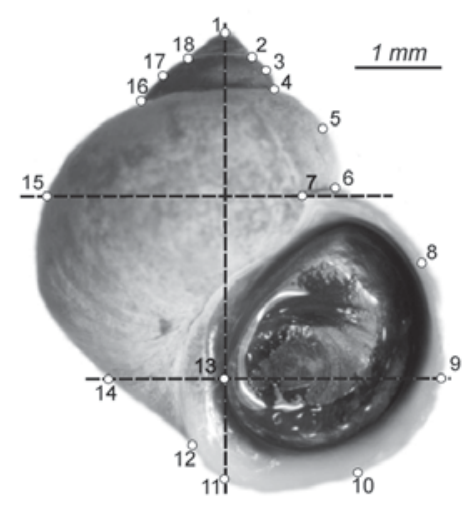

C

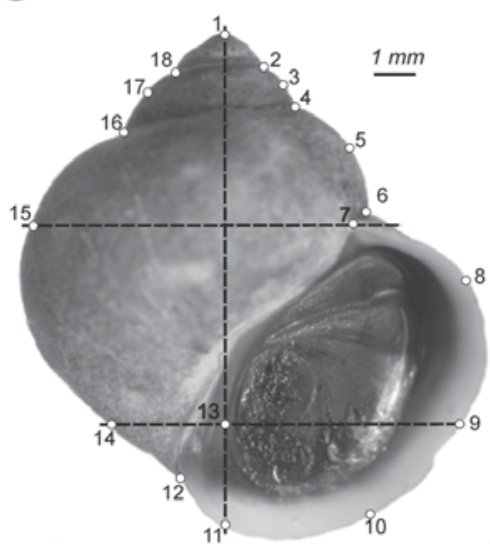

$E$

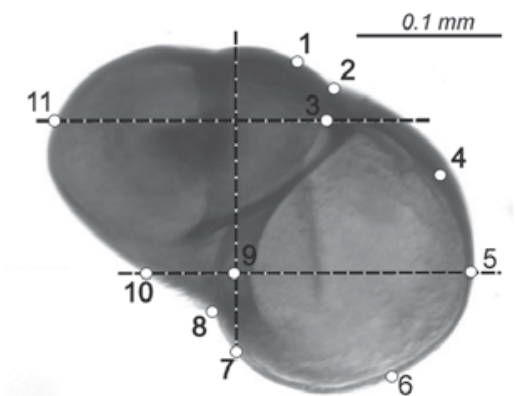

B

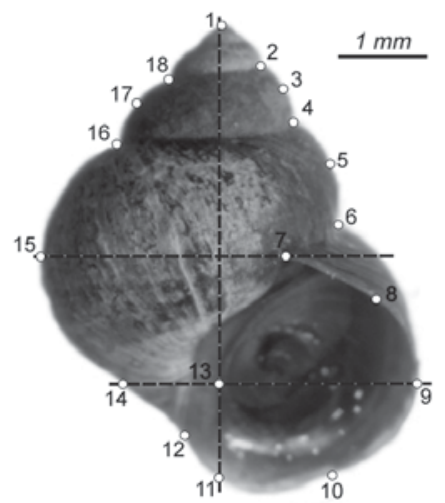

D

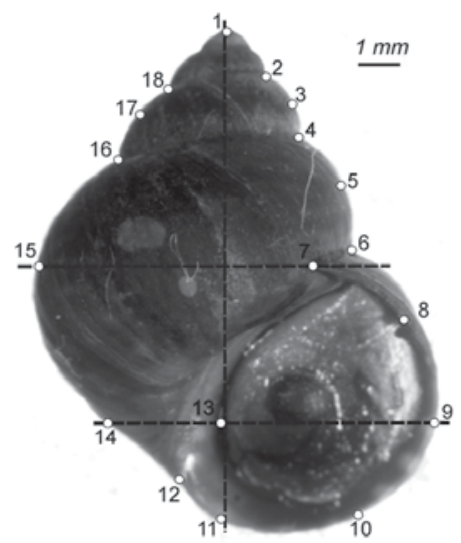

$\mathrm{F}$

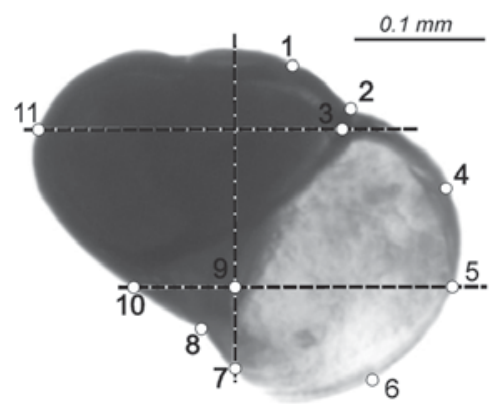

Fig. 2. Landmarks on different types of shell form. A - shell form from WLVs (adult; exposed, White Sea); B - shell form from WBG (adult; moderate, White Sea); C - shell form from BCD (adult; exposed, Barents Sea); D - shell form from BYI (adult; moderate, Barents Sea); E - embryo shell from WBG (the White Sea); F - embryo shell from BYI (Barents Sea).

Рис. 2. Метки на разных формах раковины. A - раковина из WLVs (взрослая, прибойная, Белое море); В - раковина из WBG (взрослая, умеренная, Белое море); $\mathrm{C}$ - раковина из $\mathrm{BCD}$ (взрослая, прибойная, Баренцево море); D - раковина из ВYI (взрослая, умеренная, Баренцево море); Е эмбриональная раковина WBG (Белое море); F — эмбриональная раковина (Баренцево море). 
A

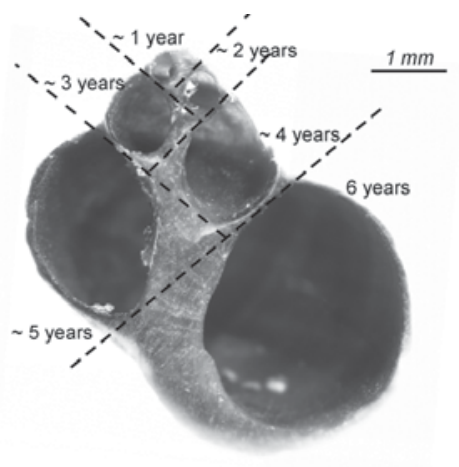

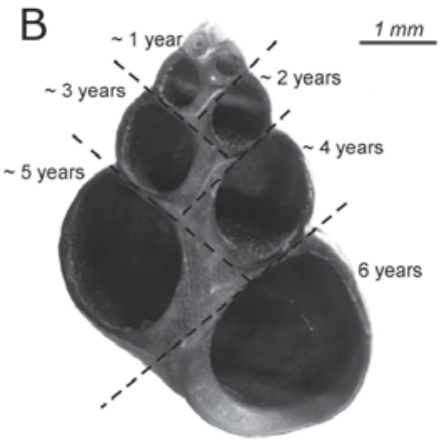

C

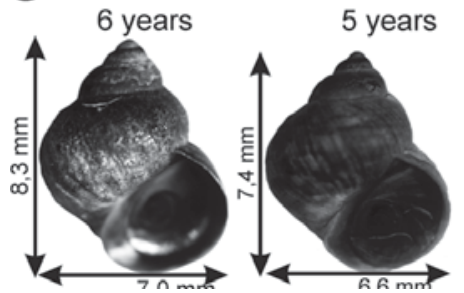

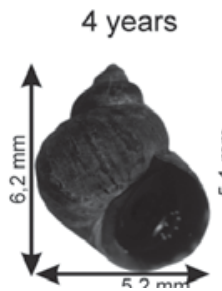

3 years

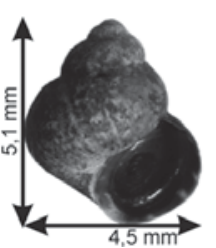

2 years

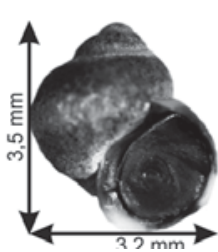

1 year old

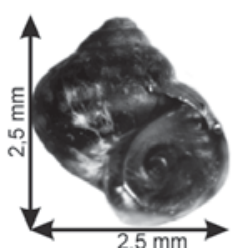

Fig. 3. Sections of the shell from A - WLV (White Sea) and B - WBG (White Sea); C - average height and width of the shells of all age groups from WBG (White Sea).

Рис. 3. Спилы раковины из A - WLV (Белое море) и В - WBG (Белое море); С - средняя высота и ширина раковин всех возрастных групп из WBG (Белое море).

(relative warps - RW) were obtained using the software TPSRELW ver. 1.53 developed by Rohlf (2005b). We used CS (the square root of the sum of the squared distances between LMs and the centroid of the LM configuration; Bookstein, 1991) as a measure of shell size in allometric analysis. The scaling option $\alpha=0$ (the weights of all LMs are equal) was used for all types of analyses, except for allometric analysis, when we used $\alpha=1$.

The RWs (1-10), U (1-2) and CS were statistically compared as shape variables using univariate and multivariate techniques. For a better understanding of the overall morphological diversity of adults and embryos, we examined the shape variation using principal component analysis (PCA). Two-way ANOVAs were done separately for the most significant RWs to determine the within and between population shell differences. The assumptions of normal distribution and variance homogeneity of residuals were checked before analyses using Levene's test. We applied Tukey's honestly signif- icant difference test (HSD) for unequal sample sizes for post hoc comparisons. A one-way ANOVA was conducted to compare the mean difference in shell size (height in $\mathrm{mm}$ ) of adult molluscs from the two geographical regions. Means are reported with $95 \%$ confidence intervals.

Multivariate regression analyses were used to detect allometry separately for adult parts of all populations and to compare mass sample data for model populations. Allometric effects were tested for 12 independent variables (two uniform and the first 10 non-uniform variables) and the CS. Subsequently, ANCOVA was used to find the relationships between size and specific components of shell shape for molluscs of all age rows. The $\mathrm{CS}$ was used as a covariate and as a measure of size, since it was highly correlated with shell height. We tested the homogeneity of the slopes of the regression lines.

Interpopulation variations in the shell shape were found in the mass sample and the longitudinal analyses and were tested with a MANO- 
VA. We determined the comparative contributions of the mass sample and the longitudinal analyses by testing the most significant variables by two-way univariate ANOVAs with the fixed factor 'age rows' and the random factor 'population'. Microsoft Excel 2010 and Statsoft Statistica 7.0 were used for all statistical analyses.

\section{Results}

\section{Testing the model}

1.1. Shell shape variation in adult $L$. saxatilis from the populations from "exposed" and "moderate" sites

The data from four populations of $L$. saxatilis from the White and the Barents Sea (see Table 1 , line 1) were studied using PCA. We extracted two principal components that together explained $94.9 \%$ of the total variation (Fig. 4A, B). The first one (PC 1) was associated with the shape components (Us, RWs) that did not depend on size, whereas the second component (PC2) correlated with a $\mathrm{CS}$.

Note that the PC1 scores differed significantly between the specimens from the two types of shores ("exposed" and "moderate", regardless of the geographical region), except for a few individuals that overlapped in the component space. Two-way ANOVA revealed that the first non-uniform component RW1 differed significantly between the "exposed" and the "moderate" populations $\left(F_{7,250}=21.56\right.$, $P=0.01$, with the highest proportion of variation seen for PC1 (Fig. 4B; Fig. 5A). Molluscs from "exposed" shores had shells with larger apertures and lower spires, while those from "moderate" shores had elongated spires (Fig. 5B). The populations from the two different geographical regions (the White and the Barents Sea) could be discriminated very well by PC2. This corresponded well with the mean difference in size of adult molluscs from the White and the Barents Sea (mean size 7.2 \pm 0.12 $\mathrm{mm}$ and $10.2 \pm 0.19 \mathrm{~mm}$, respectively, $F_{1,250}=11.4$, $P=0.05$ ). The relationship between shape components and CS was not statistically significant for any adults of the studied populations (Mul- tivariate regression analysis, Wilk's $\lambda=0.84$; $\mathrm{F}=0.37, P=0.59)$.

\subsection{Shell shape variations in pre-emerg- ing embryos of $L$. saxatilis from brood pouch- es of females from "exposed" and "moder- ate" populations}

Snail shells from different families of seven populations (see Table 1, line 2) were used to test for shell shape differences in pre-emerging individuals taken from the brood pouches of females (families) inhabiting "exposed" and "moderate" shores of both geographical regions. Series of ANOVA showed no significant differences for any shape components among the embryos from different families within each population $(F=2.6, P=0.5)$. PCA revealed random variations between different populations from two geographical region. All groups of individuals in the component space overlapped with each other (Fig. 6). The first two principal components (PC 1 and PC 2) explained only $20-80 \%$ of variability. The percentage of explained shape variance was relatively low for the other principal components (each less than $10 \%)$. Two-way ANOVA showed no significant differences for any RWs among the embryos from different brood pouches and between populations $\left(F_{7,688}=3.2, P=0.5\right)$.

\section{Comparison of age-related allom-} etry obtained from mass sample and longitudinal data.

\subsection{Analysis of mass sample data}

We used molluscs ranging from 1 to 6 years of age from the three model populations at the White Sea to assess allometric changes in the shell shape (see Table 1, line 3). Shell variables (RWs) were used to assess the shape features. CS was used as a general estimate of the shell size. Multivariate regression revealed size-dependent changes in the shell shape in all three populations (Wilk's $\lambda=0.31 ; \mathrm{F}=46.8, P<0.01$ ). For adults, the link between shell variables and CS was not significant (see below). For all age rows, the main RWs showed a significant dependence on the CS in all the populations (i.e., it explained more than $40 \%$ of the variation). 


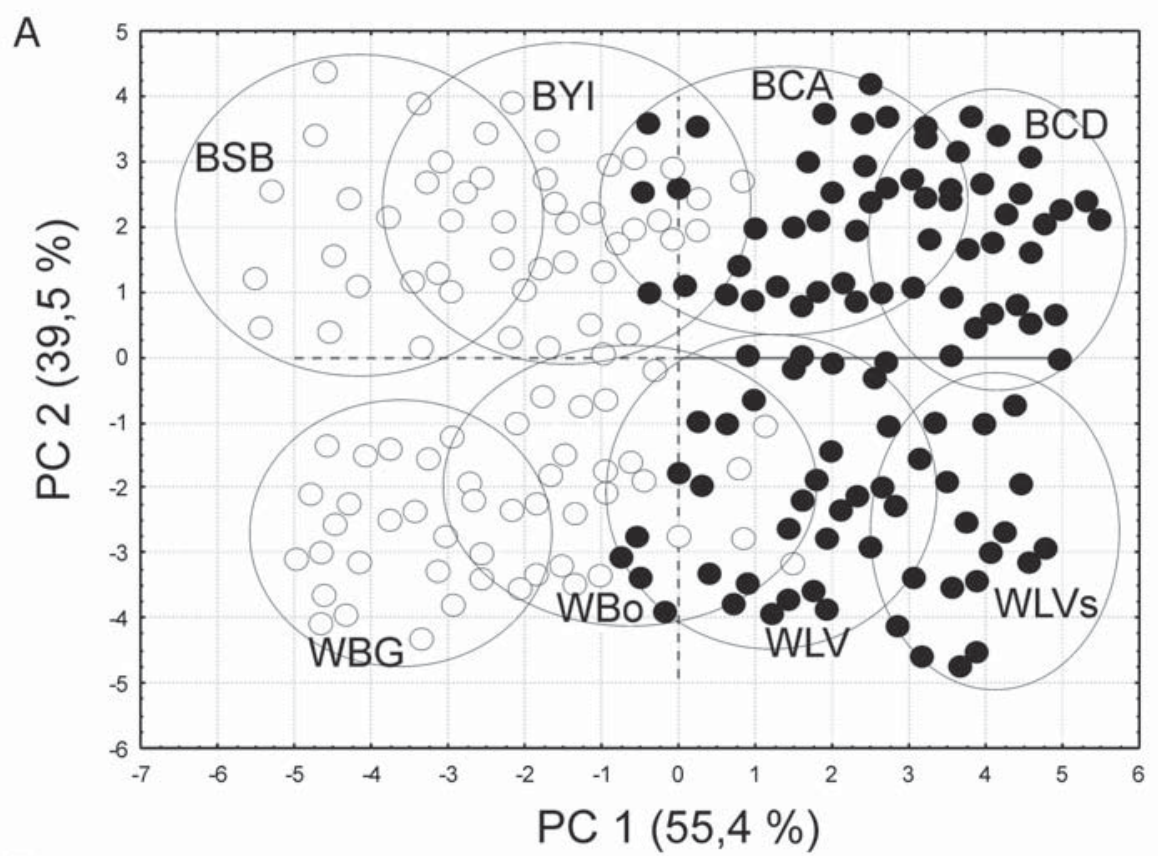

B

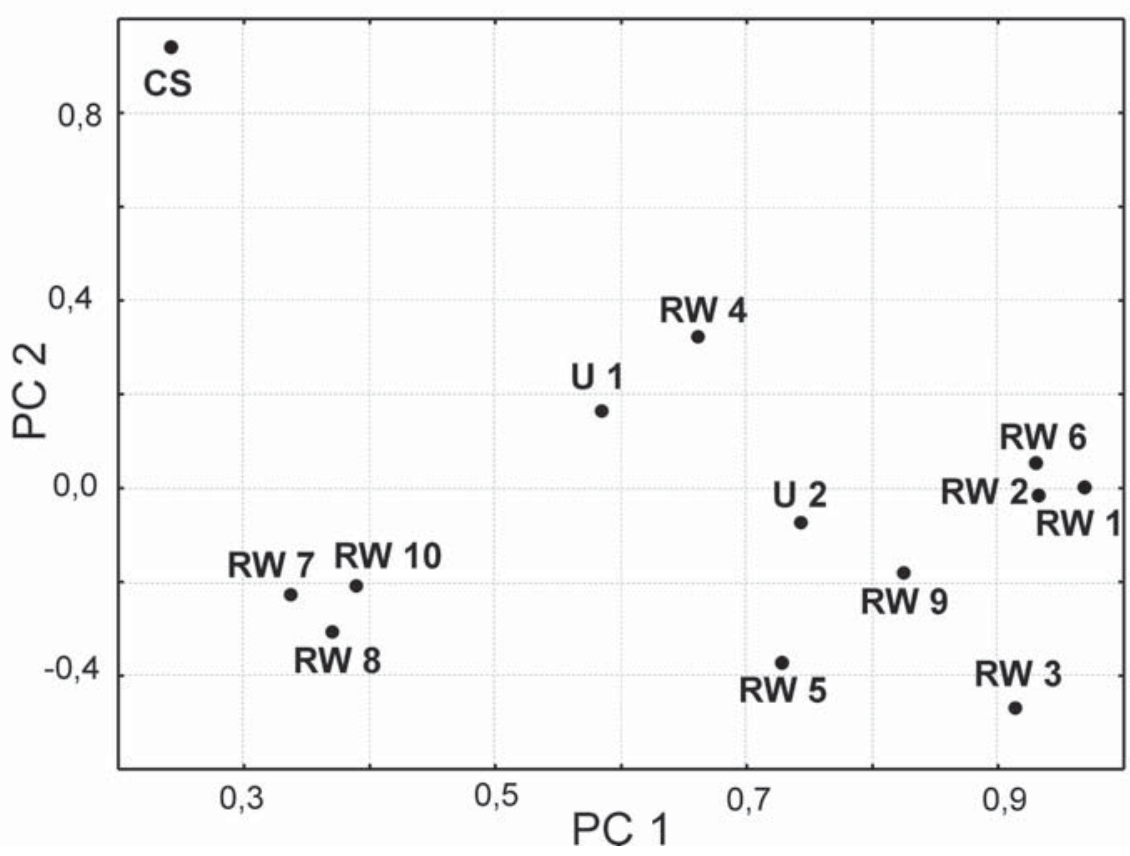

Fig. 4. Principal component analysis for the adult part of the populations. A - ordination of the specimens in the plane of the two principal components ( $\mathrm{PC} 1 ; \mathrm{PC} 2)$. Individuals from the same population are grouped in circles. B - ordination of the factor scores in the plane of the two principal components (PC1; $\mathrm{PC} 2)$. Рис. 4. Анализ главных компонент для взрослой части популяции. А - распределение особей в пространстве главных компонент (PC1; РС2). Особи из одной популяции выделены кругами. В распределение факторных оценок в плане двух главных компонент (PC1; РC2). 

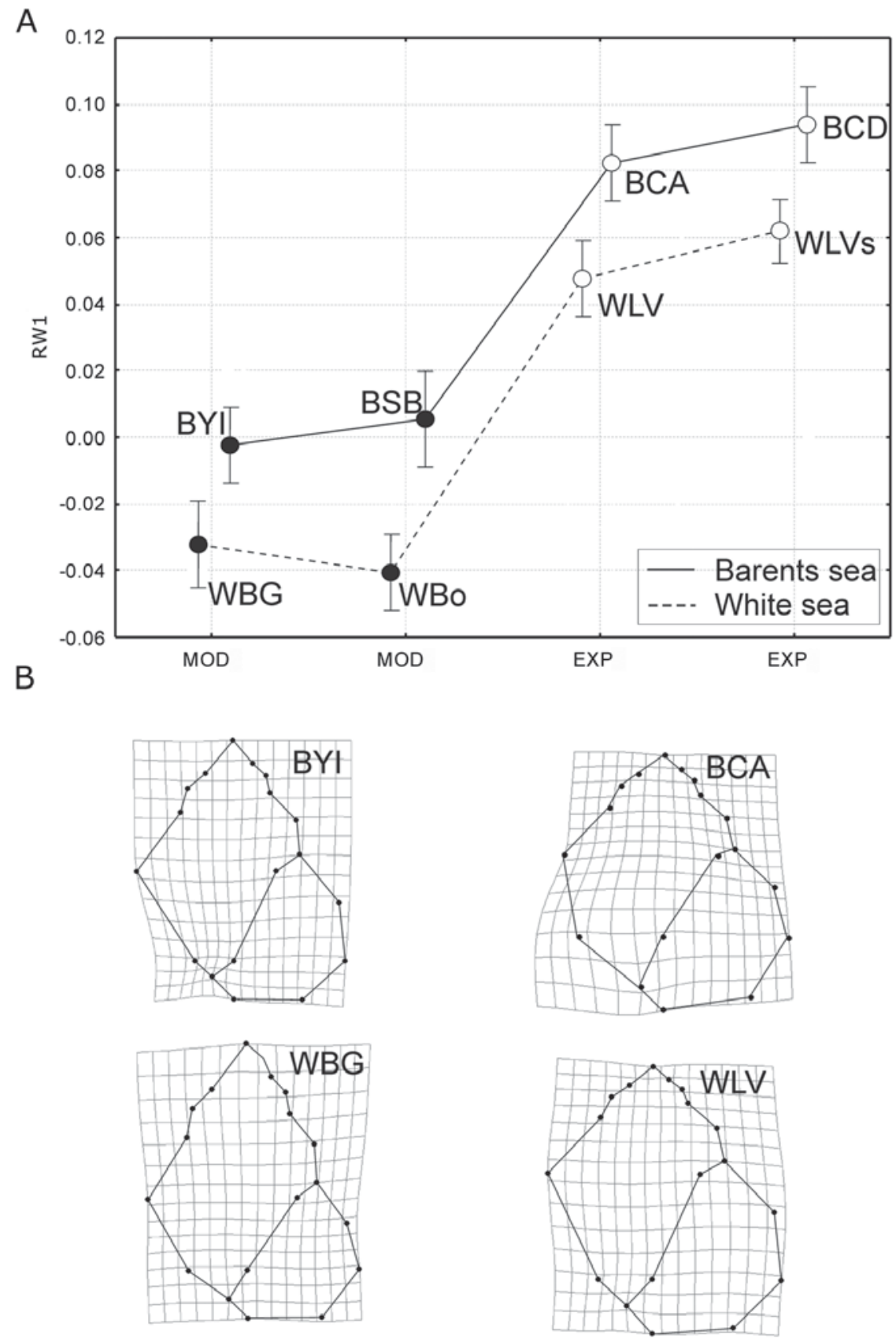

Fig. 5. Moderate and exposed populations from the White and the Barents Sea. A - mean values of Relative Warp 1 (RW 1) of moderate (MOD) and exposed (EXP) populations; B - transformation grids showing the "moderate" and the "exposed" shell form.

Рис. 5. Умеренные и прибойные популяции из Белого и Баренцева морей. А - средние значения относительных деформаций (RW 1) умеренных (MOD) и прибойных (EXP) популяций; B трансформационные решетки показывают «умеренные» и «прибойные» формы раковины. 


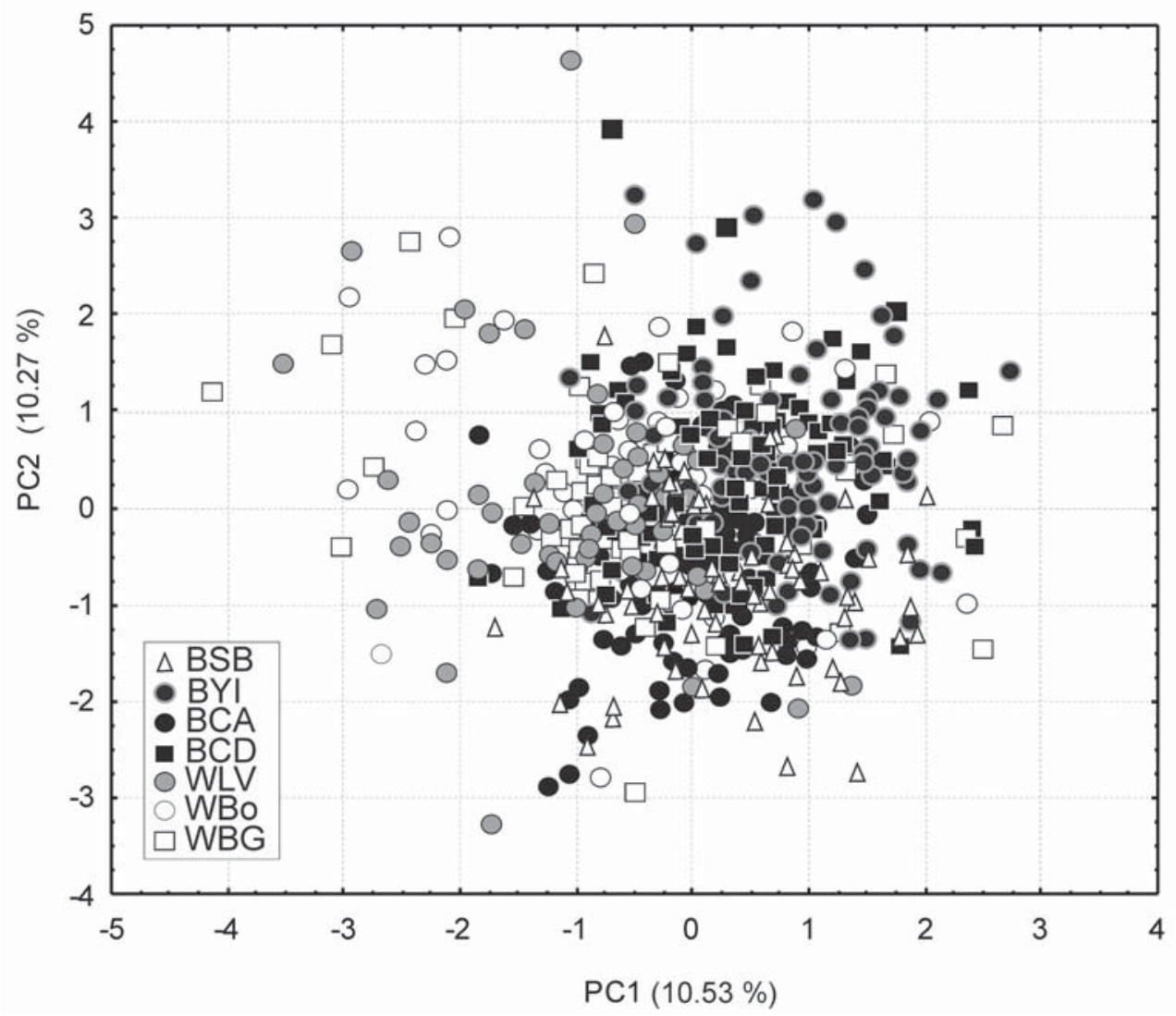

Fig. 6. Ordination of the specimens (pre-emerging embryos) of different populations in the plane of two principal components (PC1; PC2).

Рис. 6. Распределение особей (эмбрионов с раковиной) из разных популяциях в пространстве двух главных компонентов (PC1; РC2).

Specific age/size-related differences in the shell shape of the molluscs of age rows 1 to 6 were tested using ANCOVA. The second uniform component $\mathrm{U} 2(F=23.6 ; P<0.01)$ and the first non-uniform component RW1 $(F=29.8 ; P<$ $0.01)$ showed significant differences between age rows of every population. An example of this allometric change is shown for WBo population as regression slopes. Regression slopes (Fig. 7A) for all age rows (1-6) plotted for U2 versus CS suggested a significant linear relationship between size and shape only for juvenile age groups.

The results of the ANCOVA test for homogeneity of the regression slopes indicated that they were dissimilar for juveniles and adults.
Configurations of the consensus shapes (Fig. 7B) illustrated the change in shape between 1-yearold (juvenile form), 2 year-old and 3-year-old (adult form) individuals represented by LM movement along the columella and the aperture. The shell of the adults becomes more elongated along the vertical axis and its aperture becomes relatively smaller.

Specific changes in the shell shape were described using MANOVA, which revealed significant differences between age and two uniform components (U1-U2) and the first five non-uniform components (RW1-RW5) (Wilk's $\left.\lambda=0.25 ; \mathrm{F}_{(10.14)}=29.9, \mathrm{P}<0.01\right)$. We showed how shell shape could differ among the populations by plotting the most significant variable RW3 
A

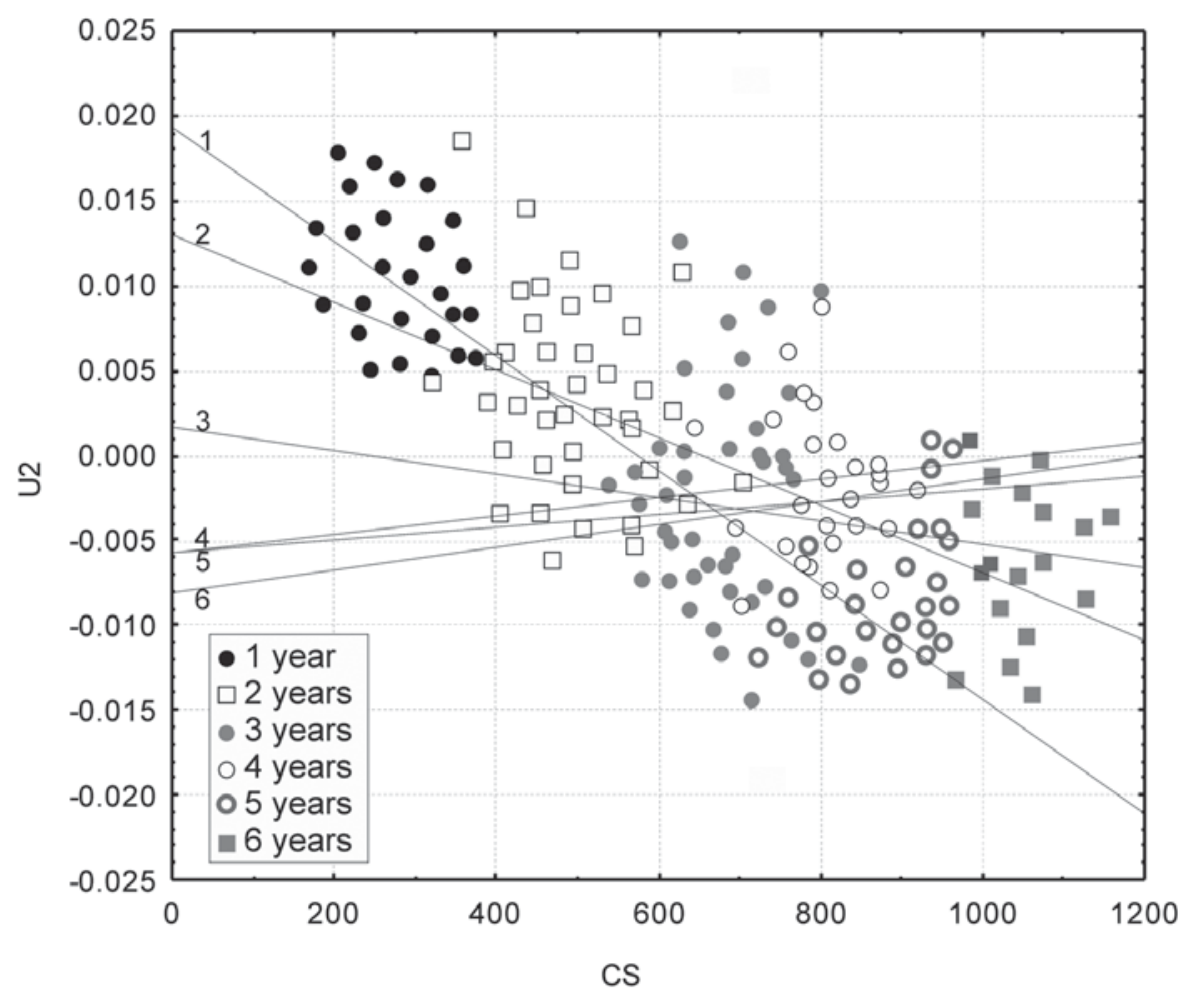

B

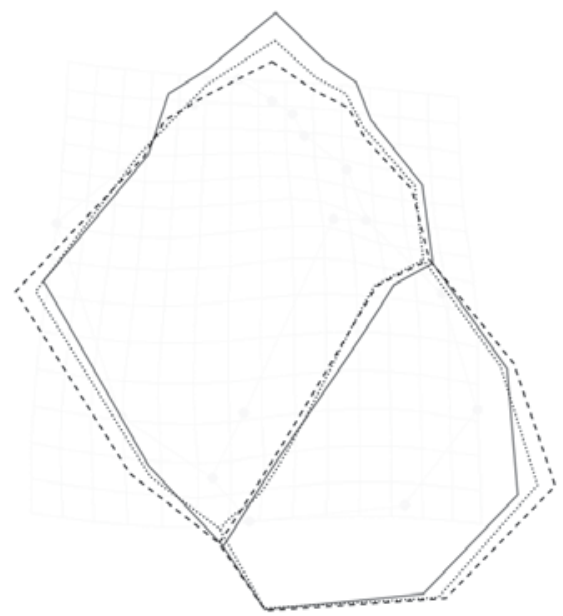

1 year

2 year

3 year

Fig. 7. Allometric analysis of shell shape for the molluscs of all ages for WBo population. A - individuals are plotted between CS and the $\mathrm{U} 2$ and regression slopes for age rows: $\mathrm{B}-\mathrm{C}$ - transformation of grids for 1- and 6-year-old individuals.

Рис. 7. Аллометрический анализ формы раковины моллюсков всех возрастов из WBo популяции. А особи распределены между CS и U2 и наклон регрессионной прямой для возрастных рядов: $\mathrm{B}-\mathrm{C}-$ трансформационные решетки для особей от одно до шести лет. 


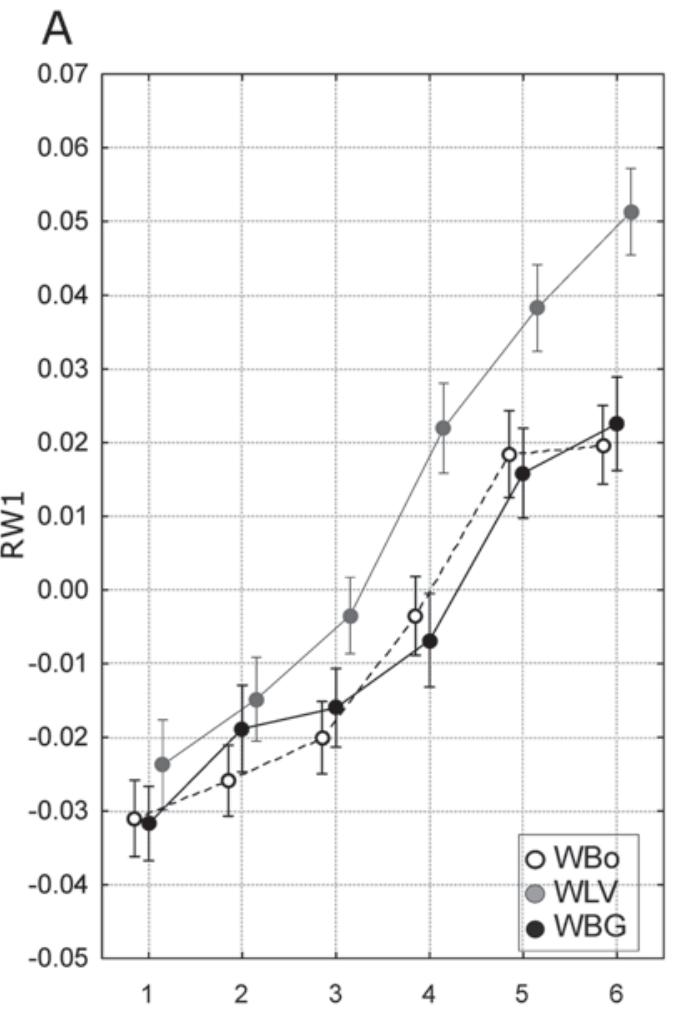

B

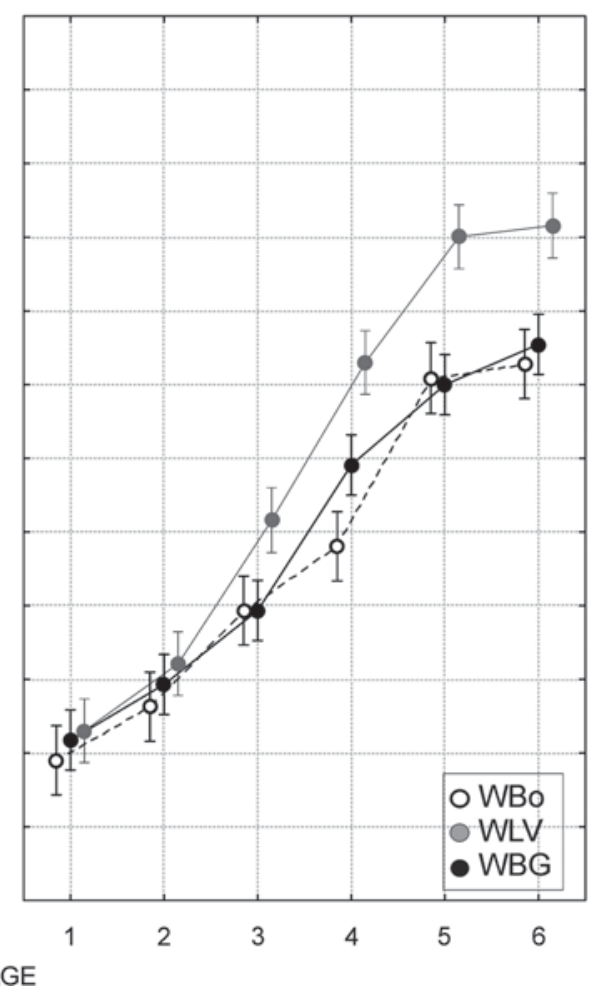

Fig. 8. Allometric changes of RW1 measured in analysis of age rows (A) and ontogenetic analysis (B). A age groups (from 1- to 6-year-old snails) from three model populations (WLV, WBG, and WBo). B individual growth of a mature snail reconstructed using shell sections.

Рис. 8. Аллометрические изменения для RW1 в анализе возрастных рядов (А) и онтогенетический анализ (В). A - возрастные группы (от одного- до шестилетних моллюсков) из трех модельных популяций (WLV, WBG и WBo). B — индивидуальный рост взрослых моллюсков реконструированные по спилам раковин.

for age rows (Fig. 8A). Note that the differences between the youngest (1-2 years) and the oldest (5-6 years) molluscs were significant across all examined populations; the difference between "exposed" population (WLV) and "moderate" populations (WBo and WBG) was significant in the 3-6 year age range.

\subsection{Analysis of longitudinal data}

Analyses of different age rows can show only population-level variation, whereas the sections of the shell helped to trace individual growth and explain how the shell shape changed through an individual's lifetime. MANOVA revealed the same differences between age and two uniform components (U1-U2) and the first five non-uniform components (RW1-RW5) (Wilk's $\lambda=0.23 ; \mathrm{F}_{10.42}=34.7, P<0.01$ ) as were revealed by the analysis of age rows (see above). Likewise, the most significant variable (RW3) was significantly different between young and old molluscs, and between the snails from "exposed" and "moderate" populations (Fig. 8B).

\subsection{Comparison of mass sample and lon- gitudinal data}

We evaluated comparative contributions of each variable by two-way univariate ANOVAs with a fixed factor of age rows and a random factor of population. The analysis was per- 
formed separately for the data of age rows and for the data of individual growth trajectories, traced using the shell sections (Table 2). The variables U2 and RW1 showed significant differences between ages, populations, and their interactions for the data on age rows and on shell sections. Variables U1 and RW4 differed between populations, and RW3 depended on the interaction Age*Population in both analyses. RW2 and RW5 depended on the Age*Population interaction in age row analysis and on the main effects of Population and Age in the analysis of shell sections. A very similar structure of the shape variation was revealed by the two analyses.

\section{Discussion}

In this study, we showed that the shell shape in the studied populations of $L$. saxatilis differed depending on differences in their environments, in particular, the degree of wave action. Wave action had the strongest impact on the shell shape on "exposed" shores and a less pronounced impact on "moderate" shores. While the size/shape characteristics of shelled embryos from brood pouches were the same in different populations (in other words, the starting point of shell growth was the same), the molluscs then underwent a period of populationspecific allometric growth for 2-3 years until their maturation. As a result, the shell shape of adult periwinkles corresponded to the degree of wave action in their environment, owing to a specific allometric growth program.

The model tested in our study had several specific features. Firstly, we tested the populations of $L$. saxatilis from the northeastern Arctic edge of its distribution. Secondly, we tested the populations from the stony shore only, differing in the degree of wave action: strong or moderate. Thirdly, there are no intertidal crabs in the study region, which commonly co-occur with L. saxatilis elsewhere (Carcinus maenas in Britain and Sweden, Pachygrapsus marmoratus in Spain [Butlin et al., 2014]), and the effect of an additional selection factor, predation, on the differentiation of the L. saxatilis ecomorphs was therefore excluded. Fourthly, the sampling was carried out at the high level of the intertidal zone, which means that the snails from differently exposed populations had been existing under a similar air exposure regime. Considering these features, we could be reasonably sure that wave action was the main factor affecting morphological traits of the molluscs in our model. To note, wave action is one of the most extensively studied factors affecting the shell shape in L. saxatilis, which means that our data could be fruitfully compared with those of other authors.

L. saxatilis from the exposed sites of the Barents and the White Sea generally have more globose shells with relatively expanded apertures. The same shell shape differences between the populations, and their correlations with the degree of the wave action, zonal position on the shore, and crab predation risk, have previously been described for $L$. saxatilis populations from north-western Sweden (Hollander, Butlin 2010); north-western Spain (Johannesson et al., 1993; Carvajal-Rodríguez, 2005; Conde-Padín et al., 2007b; Quesada et al., 2007; Conde-Padín et al., 2009), and Great Britain (Conde-Padín et al., 2007a; Grahame et al., 2006). All these morphological traits appear to have an adaptive significance and may have evolved independently at different sites (Johannesson et al., 2010; Galindo, Grahame, 2014; Rolán-Alvarez, 2007). In some studies, genetic differences in L. saxatilis ecotypes were regarded as an evidence of divergent selection at the stage of ecological speciation (Quesada et al., 2007; Galindo, Grahame, 2014; Butlin et al., 2014).

To sum up, wave action leads to the emergence of similar morphometric traits in molluscs from many different parts of $L$. saxatilis distribution, regardless of the modal size of the individuals in the populations. Similar morphometric features (a greater globosity and a relatively wider aperture) are known to correlate with the degree of wave action in populations of other gastropods (Avaca et al., 2013; Silva et al., 2013; Solas et al., 2013). These considerations indicate that the correlations under discussion may have a general evolutionary significance. 


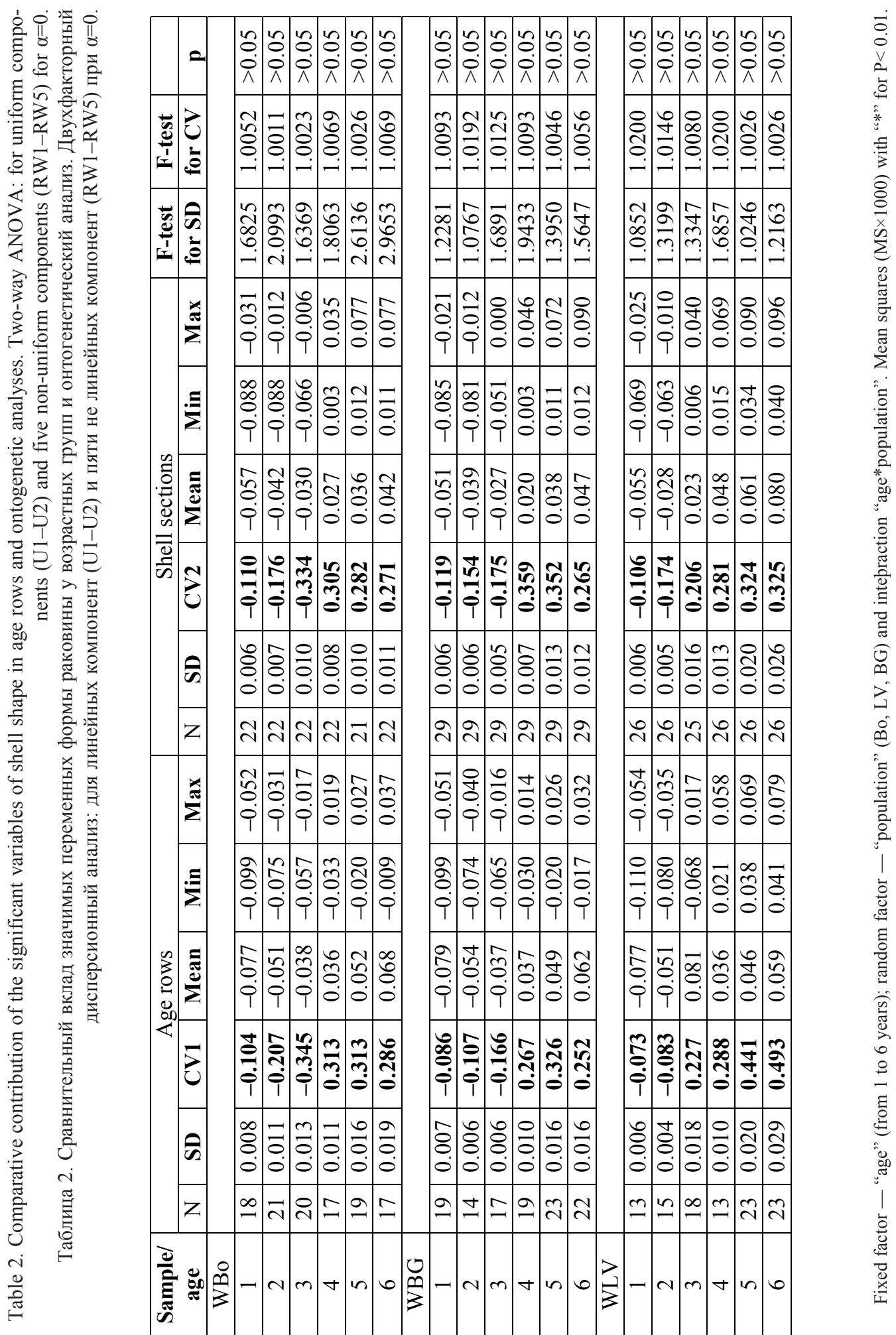


While the term "mass sample (cross sectional)" (Gould, 1966) is seldom mentioned in the literature, most ecological studies use this approach. For this, different individuals from the population are analyzed at different growth stages. In case of longitudinal approach, individuals are analyzed at different growth stages during their lifetime. The analysis of growth, from shelled embryos to adult molluscs, under controlled laboratory conditions has a number of significant limitations. Firstly, the influence of environmental factors on shell growth is for the most part left out since the conditions of the intertidal zone cannot be fully recreated in the laboratory. Secondly, such a study would take more than five years and, importantly, require special equipment.

Despite these limitations, there are some laboratory studies of molluscan growth. Transplantation experiments of newly born molluscs from the populations of NW Sweden revealed a high level of heritability (additive genetic variation) of the morphometric traits of the "exposed" E and "sheltered" S ecotypes (Hollander, Butlin, 2010), and a genetic component (connected with the ecotype) as high as $72-99 \%$ was found.

The initial shell growth allometry is supported by the data on embryos from the female brood pouches. All embryos between families within each analyzed population have no significant difference in shape due to their close relationship. Most of the embryos from one female brood pouches are half sibs which leads to the absence of shape and genetic variation. This variant of similarity in embryos is quite common in populations of $L$. saxatilis from other locations (Conde-Padín et al. 2007b, Galindo et al. 2020). Our results show that shelled embryos from the populations of both geographical regions and wave exposure levels had a similar shell shape too. Similar results are rather rare but have been obtained for prehatching stages of Acanthina monodon, another gastropod with direct development (Solas et al., 2013). Conversely, prominent differences were evident in the embryo shell shapes from the egg capsules of Nucella lapillus from exposed and sheltered sites of north-western Spain (GuerraVarela et al., 2009) and embryos of L. saxatilis of the RB and the SU ecotypes from Spain (Rolán-Alvarez, 2007). We suggest that the degree of shell shape differentiation of prehatching embryos reflects that of genetic differentiation of ecotypes according to the intensity of divergent ecological impacts on the population. We hypothesize that the genetic differentiation of the RB and the SU ecotype is much deeper than that of the L. saxatilis populations from shores with a high and a moderate wave action considered in our work. Allometric patterns of growth allow to recognize absence of variation at embryonic stage and to predict differences in further development. Growth rate of individuals may change in response to living conditions even with absence of shape variation at initial stages of development.

Our results show a prominent age-specific shell shape allometry in all the tested populations. These age-specific morphometric changes (allometric growth trajectories) differ in exposed and intermediate environments. Both allometric growth itself and its differences between individuals living in different habitats have been repeatedly reported for $L$. saxatilis (Johannesson et al., 1993; Reid, 1996; Carvajal-Rodríguez, 2005; Hollander et al., 2006; Conde-Padín et al., 2009; Hollander, Butlin, 2010; Chrismas et al., 2014). Moreover, different growth patterns have been shown to characterize L. saxatilis males and females on rocky cliffs, the males being isometric (Hollander et al., 2006). The authors regard the switch between isometric/allometric growths as juveniles to allometric/isometric growths after attaining sexual maturity as biphasic allometry (Hollander et al., 2006). In our study, data from the males and the females were equally represented in the samples. In contrast to the work cited above our data included the age determination of longliving $L$. saxatilis, which permits consideration of the same growth processes in a more gradual, extended mode. Allometry was very prominent in the youngest molluscs (1-2 years of age), slightly weakened at the age of 3 years and, finally, became negligible in the older molluscs. 
We agree that the age of maturation (the modal age of sexual maturity is 3 years for $L$. saxatilis from the Barents and White Sea populations [Granovitch et al., 2000]) is an important period for the gradual transition from a fast allometric to a slow nearly isometric growth. However, calling this dynamics of growth biphasic is questionable, especially for long-living $L$. saxatilis from the populations of the Barents and White Sea. Different modes of allometric/isometric growths shown in the $\mathrm{E}$ and the $\mathrm{S}$ L. saxatilis (Hollander et al., 2006) may reflect methodical difficulties of determining the precise age range of fast-growing European morphs.

Therefore, our data suggest that an initially fast growth of young molluscs is inevitably accompanied by allometry. The trajectories of transition from allometry to near isometric growth may differ in different populations in different environments, wherein wave action is a good specific morphometrically discriminating factor. The molluses from the Barents and the White Sea have similar starting points of morphometric growth, regardless of the degree of wave action for the population. Further shell growth is accompanied by the transition from the globose shell of the early ontogenetic stage to the more elongated shell with the relatively smaller aperture. The "end point" of these shape changes depends on the degree of wave action experienced by the population. Similar allometric trajectories were shown for different populations under the same degree of wave action. The initial mechanisms that created these parallel differences could apparently be associated with different allometric trajectories of individuals. This allometric trajectories unlikely dependent under selection but may be influenced with differential growth rates between population as growing and allometry are correlated.

From most studies discussed extent shell growth may vary among individuals, populations, and species, it makes impossible to gain on the relationship between growth rate and shape referring to allometry in gastropods. Different approaches in studying ontogenetic allometry make it difficult to compare our results to others. For instance, Urdy et al., 2010 b suppose that genetic and environmental factors on morphology are inseparable. According to results of their computer simulation the "longitudinal" and "mass sample" data from the same populations differ. As a result of simulation cross-sectional data similar to static allometry, on a plot it looks linear and studied populations have more variation among populations than among different environments. In longitudinal ontogenetic allometry different populations in different environments may have ontogenetic patterns. Because of the nonlinearities in ontogenetic trajectories sometimes it is impossible to know how much of the variation results from environment. In this work, we presented the first comparison of mass sample and longitudinal data from the same populations of $L$. saxatilis and made some conclusions regarding the features of the formation process of site-specific shell shapes. A permanent action of a strong site-specific selection may be detected if the coefficient of the morphometric characters variation $(\mathrm{CV})$ detected by mass sample data is much higher than the $\mathrm{CV}$ detected by longitudinal data. This dispersion prevalence would mean that the selection is ongoing and operating on a "proximate" level. Conversely, if the mass sample and the longitudinal approaches yield comparatively similar CV morphometric assessments, we are dealing with an "ultimate" level of selection, at which different allometric growth programs are already selectively formed in different populations and apparently become a population-specific inherited allometric growth program. We found no differences in our data either in dispersions or in the coefficients of variations in all comparisons. Therefore, our study supports the hypothesis that $L$. saxatilis populations living under contrasting wave exposure conditions implement different allometric growth programs.

Comparison of two approaches can provide interesting information regarding growth-related changes under environmental conditions in population habitats. Drastic environmental changes affecting on growth of the shell will reflect in greater dispersion of cross sectional data, since it used individuals of different ages. 
This is an inevitable consequence that impact on molluscs differ because its shells are on different stages of allometric growth. In contrast, longitudinal data, reconstructing the growth of each individual and representing the growth trajectories of the same age group of individuals should be characterized by a significantly lower dispersion; «growth response» will be much more uniform. Environmental influences can also affect growth characteristics, but in different individuals they affect similar periods of allometric growth. From this point of view, similar results obtained by mass sample and longitudinal approaches, may indicate the relative stability of the living conditions of populations in the past few years.

Acknowledgements. We are grateful to Dr. Marina Varfolmeeva for valuable comments on the statistical aspects of the study and to Natalia Lentsman for significant language improvement of the manuscript. We also appreciate very much to Prof. Rolan-Alvarez for important and very valuable comments and remarks to our study. We thank the administration of the Murmansk Marine Biological Institute of the Russian Academy of Sciences for providing opportunities for work at the biological research station in Dalnie Zelentsy and the administration of Educational and research station "Belomorskaia" of Saint Petersburg State University for providing the facilities of the field work on the White Sea. Some of the research was performed at the Resource Center for Environmental Safety Observatory and the Centre for Culture Collection of Microorganisms (Research Park of St. Petersburg State University). The study was partly supported by a grant of the Russian Scientific Foundation No. 19-14-00321. This study was partly supported by budget funding No. AAAA-A19-119020690076-7 at the Zoological Institute of the Russian Academy of Sciences.

\section{References}

Avaca M.S., Narvarte M.A., Martín P.R. 2013. Age, growth and mortality in Buccinanops globulosus (Gastropoda: Nassariidae) from Golfo Nuevo (Argentina) // Marine Biology Research. Vol.9. No.2. P.208-219.
Bookstein F.L. 1991. Morphometric tools for landmark data: geometry and biology. Cambridge University Press. New York. 512 p.

Boulding E.G., Hay T.K. 1993. Quantitative genetics of shell form in an intertidal snail: constraints on short term response to selection // Evolution. Vol.47. No.2. P.576-592.

Butlin R.K., Saura M., Charrier G., Jackson B., André C., Caballero A., Coyne J.A., Galindo J., Grahame J.W., Hollander J., Kemppainen P., Martínez-Fernández M., Panova M., Quesada H., Johannesson K., RolánAlvarez E. 2014. Parallel evolution of local adaptation and reproductive isolation in the face of gene flow // Evolution. Vol.68. No.4. P.935-949.

Carvajal-Rodríguez A., Conde-Padín P., Rolán-Alvarez E. 2005. Decomposing shell form into size and shape by geometric morphometric methods in two sympatric ecotypes of Littorina saxatilis // Journal of Molluscan Studies. Vol.71. No.4. P.313-318.

Chrismas N.A.M., Torres-Fabila B., Wilding C.S., Grahame J.W. 2014. An association of mitochondrial haplotype with shell shape in the intertidal gastropod Littorina saxatilis // Journal of Molluscan Studies. Vol.80. No.2. P.184-189.

Cock A.G. 1966. Genetical aspects of growth and form in animals // Q. Rev. Biol. Vol.41. P.131-190.

Conde-Padín P., Grahame J.W., Rolán-Alvareaz E. 2007a. Detecting shape differences in species of the Littorina saxatilis complex by morphometric analysis // Journal of Molluscan Studies. Vol.73. No.2. P.147-154.

Conde-Padín P., Carvajal-Rodríguez A., Carballo M., Caballero A., Rolán-Alvareaz E. 2007b. Genetic variation for shell traits in a direct-developing marine snail involved in a putative sympatric ecological speciation process // Evolutionary Ecology. Vol.21. P.635-650.

Conde-Padín P., Caballero A., Rolán-Alvarez E. 2009. Relative role of genetic determination and plastic responses during ontogeny for shell-shape traits subjected to diversifying selection // Evolution. Vol.63. No.5. P.1356-1363.

Galindo J., Grahame J.W. 2014. Ecological speciation and the intertidal snail Littorina saxatilis // Advances in Ecology. Vol.9. P.12.

Gould S.J. 1966. Allometry and size in ontogeny and phylogeny//Biological Reviews. Vol.41. No.4. P.587640.

Grahame J.W., Wilding C.S., Butlin R.K. 2006. Adaptation to a steep environmental gradient and an associated barrier to gene exchange in Littorina saxatilis // Evolution. Vol.60. No.2. P.268-278.

Granovitch A.I., Mikhailova N.A., Znamenskaya O., Petrova Yu.A. 2004. [Species complex of mollusks of the genus Littorina (Gastropoda: Prosobranchia) from the eastern Murman coast] // Zoologicheskij Zhurnal. Vol.83. No.11. P.1305-1316 [in Russian].

Granovitch A., Sergievsky S., Sokolova I. 2000. Spatial and temporal variation of trematode infection in coexisting populations of intertidal gastropods Littorina saxatilis and L. obtusata in the White Sea // Diseases of Aquatic Organisms. Vol.41. No.1. P.53-64. 
Guerra-Varela J., Colson I., Backeljau T., Breugelmans K., Hughes R.N., Rolán-Alvarez E. 2009. The evolutionary mechanism maintaining shell shape and molecular differentiation between two ecotypes of the dogwhelk Nucella lapillus // Evolutionary Ecology. Vol.23. No.2. P.261-280.

Hollander J., Adams D., Johannesson K. 2006. Evolution of adaptation through allometric shifts in a marine snail // Evolution. Vol.60. No.12. P.2490-2497.

Hollander J., Butlin R.K. 2010. The adaptive value of phenotypic plasticity in two ecotypes of a marine gastropod // BMC Evolutionary Biology. Vol.10. P.333.

Janson K. 1982a. Phenotypic differentiation in Littorina saxatilis Olivi (Mollusca, Prosobranchia) in a small area on the Swedish west coast // Journal of Molluscan Studies. Vol.48. No.2. P.167-173.

Janson K. 1982b. Genetic and environmental effects on the growth rate of Littorina saxatilis Olivi // Marine Biology. Vol.69. P.73-78.

Janson K. 1983. Selection and migration in two distinct phenotypes of Littorina saxatilis in Sweden // Oecologia. Vol.59. No.1. P.58-61.

Johannesson B., Johannesson K. 1996. Population differences in behaviour and morphology in the snail Littorina saxatilis: phenotypic plasticity or genetic differentiation // Journal of Zoology. Vol.240. No.3. P.475-493.

Johannesson K., Johannesson B. 1990. Genetic variation within Littorina saxatilis (Olivi) and Littorina neglecta Bean: Is L. neglecta a good species? // K. Johannesson, D.G. Raffaelli, C.J. Hannaford Ellis (eds.). Progress in Littorinid and Muricid Biology. Developments in Hydrobiology. Vol 56. Dordrecht: Springer. P.89-97.

Johannesson K., Johannesson B., Rolán-Alvarez E. 1993. Morphological differentiation and genetic cohesiveness over a micro-environmental gradient in the marine snail Littorina saxatilis // Evolution. Vol.47. No.3. P.1770-1787.

Johanesson K., Rolán-Alvarez E., Ekenda A. 1995. Incipient reproductive isolation between two sympatric morphs of the intertidal snail Littorina saxatilis // Evolution. Vol.49. No.6. P.1180-1190.

Johannesson K., Panova M., Kemppainen P., André C., Rolán-Alvarez E., Butlin R.K. 2010. Repeated evolution of reproductive isolation in a marine snail: unveiling mechanisms of speciation // Philosophical Transactions of the Royal Society. Ser.B. Vol.365. No.1547. P.1735-1747.

Klingenberg C.P. 1996. Multivariate allometry // L.F. Marcus, M. Corti, A. Loy, G. Naylor, D. Slice (eds.). Advances in morphometrics. Plenum Press. P.23-49.

Kozminsky E.V. 2006. [Determination of age in Littorina obtusata (Gastropoda, Prosobranchia)] // Zoologicheskij Zhurnal. Vol.85. No.2. P.146-157 [in Russian].

Matveeva T.A. 1974. [Ecology and life cycles of abundant species of the gastropod molluscs of the Barents and White Seas] // V. Chlebovich (ed.). Investigations of marine fauna. Leningrad: Nauka. Vol.13. P.65-190 [in Russian].

Panova M., Hollander J., Johannesson K. 2006. Sitespecific genetic divergence in parallel hybrid zones suggests nonallopatric evolution of reproductive barriers // Molecular Ecology. Vol.15. P.4021-4031.

Quesada H., Posada D., Caballero A., Morán P., RolánAlvarez E. 2007. Phylogenetic evidence for multiple sympatric ecological diversification in a marine snail // Evolution. Vol.61. P.1600-1612.

Reid D.G. 1996. Systematics and evolution of Littorina. The Ray Society. London. 463 p.

Rohlf F.J. 2005a. TpsDig2 2.04. Available at:http: // life.bio. sunysb. edu/ morph/

Rohlf F.J. 2005b. TpsRelw 1.41. Department of Ecology and Evolution, State University of New York, Stony Brook, NY. Computer program. Available at:http: // life. bio. sunysb. edu/morph/

Rolán-Alvarez E. 2007. Sympatric speciation as a byproduct of ecological adaptation in the Galician Littorina saxatilis hybrid zone // Journal of Molluscan Studies. Vol.73. No.1. P.1-10.

Rolán-Alvarez E., Boulding E.G., Austin C.J. 2015. The contribution of the genus littorina to the field of evolutionary ecology // Oceanography and Marine Biology: An Annual Review. Vol.53. P.157-214.

Rolán-Alvarez E., Erlandsson J., Johannesson K., Cruz R. 1999. Mechanisms of incomplete prezygothic reproductive isolation in an intertidal snail: testing behavioural models in wild populations // Journal of Evolutionary Biology. Vol.12. P.879-890.

Rolán-Alvarez E., Johannesson K., Erlandsson J. 1997. The maintenance of a cline in the marine snail Littorina saxatilis - the role of home site advantage and hybrid fitness // Evolution. Vol.51. No.6. P.18381847.

Silva S.E., Silva I.C., Madeira C., Sallema R., Paulo O.S., Paula J. 2013. Genetic and morphological variation in two littorinid gastropods: evidence for recent population expansions along the East African coast // Biological Journal of the Linnean Society. Vol.108. No.3. P.494-508.

Solas M.R., Sepúlveda R.D., Brante A. 2013. Genetic variation of the shell morphology in Acanthina monodon (Gastropoda) in habitats with different wave exposure conditions // Aquatic Biology. Vol.18. P.253260.

Starunova Z.I., Mikhailova N.A., Granovitch A.I. 2010. [Analysis of interpopulation and intrapopulation differences in shell shape of the species complex "saxatilis" (Mollusca: Caenogastropoda) by methods of geometric morphometry]//Vestnik St.-Peterburg State University. Vol.3. No.4. P.23-34 [in Russian].

Urdy S., Goudemand N., Bucher H., Chirat R. 2010. Growth dependent phenotypic variation of molluscan shells: implications for allometric data interpretation // J. Exp. Zool. (Mol. Dev. Evol.). Vol.314B. P.303326.

Responsible editor E.N. Temereva 